\title{
Litterfall in the Semideciduous Seasonal Forest in Southern Brazil
}

\author{
Grasiele Dick ${ }^{1}$ (1) 0000-0002-0896-546X \\ Mauro Valdir Schumacher ${ }^{1}$ (1) 0000-0003-3277-5671
}

\begin{abstract}
Litterfall and nutrient cycling are essential processes for the forest diversity and productivity maintenance. This study aims to characterize the litterfall and evaluate if it has correlations with climatic variables in the Semideciduous Seasonal Forest on advanced succession stage, in Southern Brazil. During the 2007-2010 period, the litterfall was collected every month, sorted into leaves, twigs, and miscellaneous fractions. The litterfall amount average was $7.75 \mathrm{Mg} \mathrm{ha}^{-1}$ year $^{-1}$ and leaves constituted the highest litterfall percentage (75.0\%), followed by twigs (14.7\%), and miscellaneous (10.3\%). Higher leaf amounts were recorded in August and September. The minimum air temperature was negatively correlated with the leaves and twigs production, that is, the litterfall amount increases when the air temperature decreases. The litterfall amount corresponds to values expected to advanced successional stage of the forest typology studied. In Semideciduous Seasonal Forest in Southern Brazil, the thermal stress exerts influence on the litterfall amount.
\end{abstract}

Keywords: nutrient cycling, forest nutrition, seasonality.

\section{INTRODUCTION AND OBJECTIVES}

Brazil has many types of native forest, and the Semideciduous Seasonal Forest occurs between the South and the Southeast of the country (Ivanauskas \& Assis, 2012). This forest is considered an important ecosystem in the Atlantic Forest phytogeographic domain for the diversity and conservation of flora, shelter for fauna, and other functions exerted by forests (Viani et al., 2011).

For this forest productivity and diversity maintenance, the nutrient cycling process is an essential mechanism (Santos Neto et al., 2015). Promoted by litterfall, litter decomposition and mineralization make nutrients available in the soil for absorption by roots, and subsequent transfer to different parts of plants (Poggiani, 2012). Therefore, the knowledge on litterfall rates in the physiognomies composing the Atlantic Forest phytogeographic domain is essential, given the current degree of anthropization (Pereira et al., 2008).

In addition to being an ecological indicator for restoration evaluation of degraded areas, litterfall has an important role in the recovery of soil fertility in the initial stages of ecological succession (Alonso et al., 2015). Litterfall on the forest floor, such as leaves, branches, twigs, barks, and other plant materials, decomposes, and mineralizes to form organic matter, which serves as a nutrient pool (Kimmins, 1987).
The dynamics of production of deciduous plant material and its seasonality may vary according to the forest successional stage (Menezes et al., 2015) and disturbance degree (Poggiani, 2012).

The litterfall amount also varies among different types of forest and ecosystems (Kimmins, 1987). Especially in the Semideciduous Seasonal Forest, litterfall studies in Brazil, carried out in different successional stages, indicated the litterfall amount varied according to the forest conservation, where it is more intense in advanced successional stages, decreasing in initial succession (Pinto et al., 2009; Werneck et al., 2001). In these varied situations, the species diversity and climatic conditions can influence the litterfall amount (Dias et al., 2002; Toledo et al., 2002). The objective of this study was to characterize the litterfall and evaluate if it has correlations with climatic variables on the Semideciduous Seasonal Forest in advanced succession stage, in Southern Brazil.

\section{MATERIALS AND METHODS}

\subsection{Study area}

The study was carried in Quedas do Iguaçu, Southwest region of the Paraná state, Brazil (central geographical coordinates $25^{\circ} 27^{\prime} 22^{\prime \prime} \mathrm{S} ; 52^{\circ} 54^{\prime} 39^{\prime \prime} \mathrm{W}$ ). The site has

${ }^{1}$ Universidade Federal de Santa Maria (UFSM), Santa Maria, RS, Brasil 
13,000 ha area, covered by two types of native forests (Semideciduous Seasonal and Mixed Ombrophilous Forests) in different conservation stages, surrounded by pulp plantations of Araucaria angustifolia (Bertol.) Kuntze, Pinus spp. and Eucalyptus spp. The study area was delimited just in a remnant of the Semideciduous Seasonal Forest in advanced succession stage.

A floristic survey in the study area (Viani et al., 2011) indicates richness of the following botanical families: Fabaceae (16 species), Lauraceae (8 species), Myrtaceae (7 species) and Solanaceae (7 species). The authors mentioned above found 1,500 tree $\mathrm{ha}^{-1}$ average density in this forest typology, where the most abundant species Actinostemon concolor (Spreng.) Müll.Arg., Nectandra megapotamica (Spreng.) Mez, Lonchocarpus campestris Mart. ex Benth., Syagrus romanzoffiana (Cham.) Glassman,
Sebastiania brasiliensis Spreng., Diatenopteryx sorbifolia Radlk., and Balfourodendron riedelianum (Engl.) Engl. are typical of Semideciduous Seasonal Forests in advanced succession stages.

The humid subtropical climate characterized by hot summers, with an average annual temperature of $20^{\circ} \mathrm{C}$, $1,780 \mathrm{~mm}$ average annual rainfall and $60 \mathrm{~mm}$ in the driest month (Matzenauer et al., 2011). The region is characterized by two seasons: rainy summer and winter characterized by physiological drought and temperatures below $15^{\circ} \mathrm{C}$ (Table 1).

The study area relief is undulating and the altitude is $450 \mathrm{~m}$ in relation to the average sea level (FUPEF, 2001). The predominant soil class is the typical Dystroferric Red Oxisol, characterized by low fertility and $\mathrm{Fe}_{2} \mathrm{O}_{3}$ levels varying between $18 \%$ and $36 \%$ up to $100 \mathrm{~cm}$ depth in the B-horizon (EMBRAPA, 2013).

Table 1. Monthly variation on air temperature and pluviometric precipitation during the study period, in the Semideciduous Seasonal Forest in Southern Brazil.

\begin{tabular}{|c|c|c|c|c|c|c|c|c|c|c|c|c|c|}
\hline \multirow{2}{*}{ Variables } & \multirow{2}{*}{ Year } & \multicolumn{12}{|c|}{ Month } \\
\hline & & Mar & Apr & May & June & July & Aug & Sept & Oct & Nov & Dec & Jan & Feb \\
\hline \multirow{4}{*}{$\operatorname{Tm} \min \left({ }^{\circ} \mathrm{C}\right)$} & 2007-2008 & 19.5 & 17.6 & 11.7 & 12.0 & 9.8 & 12.4 & 15.9 & 17.6 & 16.7 & 19.1 & 19.5 & 19.5 \\
\hline & 2008-2009 & 18.9 & 18.8 & 16.3 & 15.0 & 14.5 & 16.3 & 16.9 & 18.8 & 19.5 & 19.6 & 19.7 & 19.8 \\
\hline & $2009-2010$ & 20.0 & 19.1 & 17.0 & 15.2 & 15.4 & 16.4 & 18.0 & 18.7 & 19.9 & 19.8 & 20.6 & 21.0 \\
\hline & $2010-2011$ & 20.3 & 18.4 & 16.6 & 14.7 & 15.0 & 14.3 & 17.1 & 18.5 & 19.3 & 20.6 & 20.3 & - \\
\hline \multirow{4}{*}{$\operatorname{Tmax}\left({ }^{\circ} \mathrm{C}\right)$} & 2007-2008 & 31.9 & 29.1 & 22.7 & 24.0 & 21.9 & 25.5 & 30.3 & 29.0 & 28.6 & 31.5 & 29.7 & 30.2 \\
\hline & 2008-2009 & 30.0 & 28.9 & 25.7 & 25.7 & 25.2 & 28.4 & 29.3 & 30.8 & 29.8 & 29.9 & 30.5 & 30.0 \\
\hline & $2009-2010$ & 30.3 & 28.8 & 27.7 & 25.5 & 26.3 & 27.7 & 29.3 & 29.5 & 31.4 & 30.2 & 30.2 & 30.9 \\
\hline & $2010-2011$ & 30.9 & 29.0 & 27.5 & 27.0 & 27.1 & 28.1 & 29.8 & 29.9 & 29.8 & 30.3 & 28.5 & - \\
\hline \multirow{4}{*}{$\begin{array}{c}\text { Ptmin } \\
(\mathrm{mm})\end{array}$} & $2007-2008$ & 85.0 & 208.8 & 234.4 & 22.2 & 71.8 & 10.2 & 16.0 & 99.0 & 151.8 & 301.0 & 77.4 & 161.8 \\
\hline & 2008-2009 & 16.1 & 130.0 & 102.1 & 243.2 & 110.3 & 247.5 & 290.2 & 289.2 & 162.8 & 69.3 & 218.1 & 161.2 \\
\hline & $2009-2010$ & 67.5 & 19.9 & 127.7 & 65.7 & 272.6 & 181.6 & 428.0 & 412.4 & 537.6 & 265.3 & 214.9 & 125.3 \\
\hline & 2010-2011 & 183.5 & 355.3 & 99.6 & 2.0 & 168.6 & 15.0 & 170.3 & 155.7 & 209.8 & 334.6 & 327.0 & 266.3 \\
\hline \multirow{4}{*}{$\begin{array}{c}\text { Ptmax } \\
(\mathrm{mm})\end{array}$} & 2007-2008 & 44.0 & 80.0 & 55.0 & 19.0 & 35.0 & 6.0 & 9.0 & 35.0 & 67.0 & 66.8 & 26.0 & 46.0 \\
\hline & 2008-2009 & 7.8 & 54.7 & 31.9 & 80.0 & 46.5 & 59.5 & 153.2 & 62.5 & 44.3 & 20.6 & 55.9 & 484 \\
\hline & 2009-2010 & 19.6 & 11.5 & 91.5 & 36.4 & 93.4 & 69.8 & 97.6 & 114.5 & 112.6 & 78.2 & 49.2 & 43.2 \\
\hline & $2010-2011$ & 80.9 & 149.9 & 39.6 & 1.4 & 41.9 & 6.0 & 61.1 & 49.0 & 79.7 & 49.6 & 53.9 & 73.9 \\
\hline
\end{tabular}

Tmin: average minimum air temperature; Tmax: average maximum air temperature; Ptmin: minimum total pluviometric precipitation; Ptmax: maximum total pluviometric precipitation.

Source: Weather station of Araupel S.A. company, 2007-2011. 


\subsection{Litterfall sampling}

Three plots with $20 \mathrm{~m} \times 20 \mathrm{~m}$ dimensions were installed to collect litterfall in the Semideciduous Seasonal Forest. Installed 20 meters away from the forest border, the plots were maintained 30 meters of minimum distance between each other, randomly distributed. In each plot was installed four litterfall collectors with $1 \mathrm{~m}^{2}$ area, made of shading-net ( $1 \mathrm{~mm}$ mesh) and $0.70 \mathrm{~m}$ suspended above the soil level. From January 2007 to December 2010, all the litterfall deposited in these plots was collected every month and sent to the laboratory. The litterfall samples were sorted into leaves, twigs (diameter $\leq 0.5 \mathrm{~cm}$ ), and miscellaneous fractions (i.e., flowers, seeds, fruits, and other residues). The samples fractions were dried in a circulation oven at $70{ }^{\circ} \mathrm{C}$ for 72 hours, followed by weighing in a balance ( $0.01 \mathrm{~g}$ accuracy).

Based on the data of monthly litterfall collections, the average year amount produced was estimated with the equation PS $=(\Sigma$ PMS $\times 10,000) /$ AC, where: PS $=$ annual litterfall $\left(\mathrm{Mg} \mathrm{ha}^{-1}\right.$ year $\left.^{-1}\right), \mathrm{PMS}=$ monthly litterfall $\left(\mathrm{Mg} \mathrm{ha}^{-1} \mathrm{month}^{-1}\right)$, and $\mathrm{AC}=$ collector area $\left(\mathrm{m}^{2}\right)$ (Lopes et al., 2002).

\subsection{Data analysis}

The litterfall data were submitted to analysis of variance (ANOVA) in a completely randomized experimental design. The Scott-Knott test $(\alpha=5 \%)$ was applied to evaluate differences in the monthly average litterfall (leaves, twigs and miscellaneous) between treatments (i.e. months). For ANOVA, four values (samples) were considered for each month (treatments) during the 2007-2010 period. The correlations between litterfall and climatic variables were evaluated by Pearson's bilateral test. All analyzes were performed with Assistat version 7.7 (Silva \& Azevedo, 2002).

\section{RESULTS AND DISCUSSION}

The total litterfall amount in the Semideciduous Seasonal Forest in the four years of evaluation was $31.01 \mathrm{Mg} \mathrm{ha}^{-1}$, with an annual average value of $7.75 \mathrm{Mg} \mathrm{ha}^{-1}$ year $^{-1}$. The leaves were the predominated fraction of the litterfall (75.0\%), followed by twigs (14.7\%), and miscellaneous (10.3\%) (Table 2).

Table 2. Litterfall in the Semideciduous Seasonal Forest in Southern Brazil.

\begin{tabular}{|c|c|c|c|c|}
\hline & Leaves & Twigs & Miscellaneous & Total \\
\hline \multicolumn{5}{|l|}{2007} \\
\hline Total $\left(\mathrm{Mg} \mathrm{ha}^{-1}\right.$ year $\left.^{-1}\right)$ & 5.93 & 1.67 & 0.92 & 8.57 \\
\hline Monthly average $\left(\mathrm{Mg} \mathrm{ha}^{-1}\right)$ & 0.49 & 0.13 & 0.76 & 0.71 \\
\hline Percentage (\%) & 69.7 & 19.5 & 10.8 & 100 \\
\hline \multicolumn{5}{|l|}{2008} \\
\hline Total $\left(\mathrm{Mg} \mathrm{ha}^{-1}\right.$ year $\left.^{-1}\right)$ & 5.29 & 1.00 & 0.80 & 7.09 \\
\hline Monthly average $\left(\mathrm{Mg} \mathrm{ha}^{-1}\right)$ & 0.44 & 0.83 & 0.66 & 0.59 \\
\hline Percentage (\%) & 74.6 & 14.1 & 11.3 & 100 \\
\hline \multicolumn{5}{|l|}{2009} \\
\hline Total $\left(\mathrm{Mg} \mathrm{ha}^{-1}\right.$ year $\left.^{-1}\right)$ & 5.85 & 1.08 & 0.38 & 7.31 \\
\hline Monthly average $\left(\mathrm{Mg} \mathrm{ha}^{-1}\right)$ & 0.48 & 0.90 & 0.31 & 0.60 \\
\hline Percentage (\%) & 80.0 & 14.8 & 5.2 & 100 \\
\hline \multicolumn{5}{|l|}{2010} \\
\hline Total $\left(\mathrm{Mg} \mathrm{ha}^{-1}\right.$ year $\left.^{-1}\right)$ & 6.11 & 0.83 & 1.10 & 8.04 \\
\hline Monthly average $\left(\mathrm{Mg} \mathrm{ha}^{-1}\right)$ & 0.50 & 0.69 & 0.91 & 0.67 \\
\hline \multirow[t]{2}{*}{ Percentage (\%) } & 75.9 & 10.4 & 13.7 & 100 \\
\hline & \multicolumn{4}{|c|}{ Period averages } \\
\hline Annual average $\left(\mathrm{Mg} \mathrm{ha}^{-1}\right.$ year $\left.^{-1}\right)$ & 5.81 & 1.14 & 0.80 & 7.75 \\
\hline Standard deviation & 0.24 & 0.07 & 0.05 & 0.31 \\
\hline $\mathrm{CV}$ & 4.13 & 6.14 & 6.25 & 4.00 \\
\hline Percentage (\%) & 75.0 & 14.7 & 10.3 & 100 \\
\hline
\end{tabular}

CV: coefficient of variation. 
The species diversity of this floristic composition (Viani et al., 2011) and partial deciduality provided continuous patterns of litterfall during the evaluated periods. The large litterfall amounts produced by varied species is a factor directly related to accelerated nutrient cycling, more organic matter formation, soil fertility increase, and soil protection (Kimmins, 1987).

The litterfall amounts, ranging from 7.09 to 8.57 $\mathrm{Mg} \mathrm{ha}^{-1}$ year $^{-1}$, correspond to values expected to advanced successional stage of the forest studied. The litterfall amount in this type of Semideciduous Seasonal Forest can vary from 5.09 to over $12.00 \mathrm{Mg} \mathrm{ha}^{-1}$ year $^{-1}$ depending on succession stages (Table 3). In this forest typology, litterfall amounts in advanced stage tends to be higher than those of areas in initial succession.

The floristic composition variability, species abundance between succession stages (Viani et al., 2011) and soil fertility influenced the litterfall amount of the Semideciduous Seasonal Forest (Pinto et al., 2009). The litterfall amount variation was also related to forests conservation status and seasonality climatic variables effect (Werneck et al., 2001).

About the litterfall composition and seasonality, twigs and miscellaneous varied according to the month and year, but regarding the amount of leaves, same tendencies are observed over time (Figure 1). The monthly variability of miscellaneous in litterfall composition is related to the amount of flowers, fruits and seeds produced by different species, with varied phenological phases; temporal heterogeneity on twigs amounts is a senescence physiological reflection (Taiz \& Zeiger, 2013) and an influence of other events (i.e., trees falls, rainfall, lightning and strong winds) (Pinto et al., 2009).

Table 3. Litterfall in different succession stages of the Semideciduous Seasonal Forest typology, Brazil.

$\begin{array}{ccl}\text { Semideciduous Seasonal Forest } & \begin{array}{c}\text { Litterfall } \\ \left(\mathbf{M g ~ h a}^{-1} \text { year }^{-1}\right)\end{array} & \text { Source } \\ & 8.21 & \text { Pimenta et al. (2011) } \\ \text { Advanced succession stage } & 9.50 & \text { Pezzato \& Wisniewski (2006) } \\ & 11.70 & \text { Pezzato \& Wisniewski (2006) } \\ & 8.82 & \text { Pinto et al. (2009) } \\ & 12.97 & \text { Toledo et al. (2002) } \\ & 6.78 & \text { Werneck et al. (2001) } \\ \text { Intermediary succession stage } & 8.81 & \text { Pinto et al. (2009) } \\ \text { Initial succession stage } & 6.58 & \text { Werneck et al. (2001) } \\ & 6.31 & \text { Pinto et al. (2009) } \\ & \text { Riparian forest } & \text { Werneck et al. (2001) } \\ \text { Gaps in forest } & 6.09 & \text { Pinto et al. (2009) } \\ \text { Others } & 10.00 & \text { Vital et al. (2004) } \\ \end{array}$
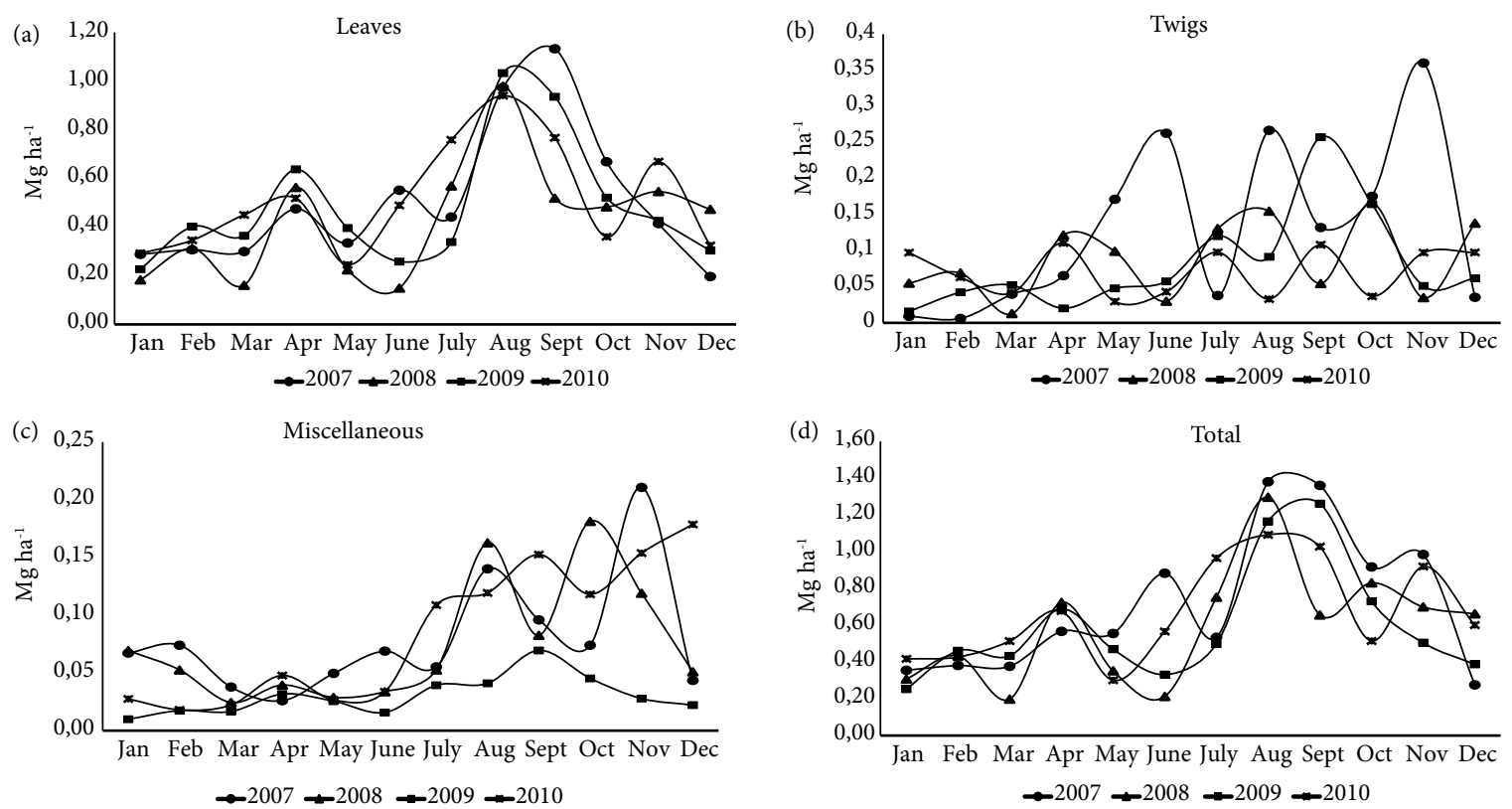

Figure 1. Seasonality of litterfall in the Semideciduous Seasonal Forest in Southern Brazil. 
Leaves in the litterfall composition are results found in all studies, regardless of forest typology or succession stage (Poggiani, 2012). Leaves are rich in nutrients, and the cycling fastest route can be used as a total litterfall indicator, as it follows the same tendencies of production (Pinto et al., 2009). Out of all the litterfall, leaves decomposition is more accelerated, and large amounts of this component in the litterfall contribute to the continuous organic matter formation and productive capacity of this forest (Ferreira et al., 2014).

Considering the litterfall monthly averages, the twigs amount and miscellaneous did not vary, but leaf production was higher in August and September, corresponding to 30\% of the total litterfall of leaves (Table 4).

In August and September, the highest amount of leaves in the litterfall reflects the plant physiological responses to thermal stress (Taiz \& Zeiger, 2013), caused by the lower temperatures recorded in July; in the study area, the minimum temperature in this period was lower than $15^{\circ} \mathrm{C}$ (Table 1). These results are corroborated by the correlation analyses that indicate the minimum air temperature negatively correlated with the leaves and twigs production (Table 5), that is, the litterfall amount (75\% leaves in composition) increases when the air temperature decreases.
The seasonal leaves fall occurs due to endogenous hormonal regulation, by thermal stress, triggering a cascade of physiological events in the plant, finishing with leaves abscission (Dias et al., 2002). However, climatic extreme absence (intense and dry cold prolonged periods), coupled with floristic diversity in this Semideciduous Seasonal Forest, allows the forest to litterfall throughout the year (Viani et al., 2011).

In others litterfall studies of the seasonal forest in Southern Brazil, the peak of leaves production were also reported in September when the temperature begins to rise, indicated as a tendency of this forest in the South region (König et al., 2002; Pimenta et al., 2011). The growth stagnation caused by winter leads to senescent foliage elimination, optimal utilization aiming to new growth period, which begins in Spring, with the new foliage appearance (Toledo et al., 2002).

In this forest in Southern Brazil, the thermal stress influence on the litterfall amount is corroborated. However, in the same type of forest in the Southeast country region. where air temperature extremes are not pronounced, the pluviometric precipitation is a more effective factor that influences litterfall amount, with peaks after water deficit (Dias et al., 2002; Pinto et al., 2009; Toledo et al., 2002).

Table 4. Monthly values (average \pm standard deviation) of litterfall in the Semideciduous Seasonal Forest in Southern Brazil.

\begin{tabular}{|c|c|c|c|c|}
\hline \multirow{2}{*}{ Months } & Leaves & Twigs & Miscellaneous & Total \\
\hline & \multicolumn{4}{|c|}{$\mathrm{Mg} \mathrm{ha}^{-1}$} \\
\hline January & $0.25 \pm 0.05 c^{*}$ & $0.06 \pm 0.03 \mathrm{a}$ & $0.04 \pm 0.03 \mathrm{a}$ & $0.35(4.5)$ \\
\hline February & $0.34 \pm 0.04 c$ & $0.06 \pm 0.01 \mathrm{a}$ & $0.04 \pm 0.02 \mathrm{a}$ & $0.44(5.7)$ \\
\hline March & $0.31 \pm 0.12 c$ & $0.04 \pm 0.01 \mathrm{a}$ & $0.03 \pm 0.01 \mathrm{a}$ & $0.38(4.9)$ \\
\hline April & $0.55 \pm 0.06 b$ & $0.08 \pm 0.05 \mathrm{a}$ & $0.04 \pm 0.01 \mathrm{a}$ & $0.67(8.6)$ \\
\hline May & $0.30 \pm 0.07 c$ & $0.07 \pm 0.06 \mathrm{a}$ & $0.03 \pm 0.01 \mathrm{a}$ & $0.40(5.2)$ \\
\hline June & $0.36 \pm 0.18 c$ & $0.10 \pm 0.01 \mathrm{a}$ & $0.04 \pm 0.02 \mathrm{a}$ & $0.50(6.4)$ \\
\hline July & $0.53 \pm 0.11 b$ & $0.10 \pm 0.04 \mathrm{a}$ & $0.06 \pm 0.03 \mathrm{a}$ & $0.69(8.9)$ \\
\hline August & $0.98 \pm 0.03 a$ & $0.14 \pm 0.10 \mathrm{a}$ & $0.12 \pm 0.05 a$ & $1.24(16.0)$ \\
\hline September & $0.84 \pm 0.35 \mathrm{a}$ & $0.14 \pm 0.08 \mathrm{a}$ & $0.10 \pm 0.03 \mathrm{a}$ & $1.08(13.9)$ \\
\hline October & $0.51 \pm 0.12 b$ & $0.14 \pm 0.06 \mathrm{a}$ & $0.10 \pm 0.06 \mathrm{a}$ & $0.75(9.7)$ \\
\hline November & $0.51 \pm 0.12 b$ & $0.14 \pm 0.04 \mathrm{a}$ & $0.13 \pm 0.07 \mathrm{a}$ & $0.78(10.1)$ \\
\hline December & $0.32 \pm 0.11 c$ & $0.08 \pm 0.04 \mathrm{a}$ & $0.07 \pm 0.07 \mathrm{a}$ & $0.47(6.1)$ \\
\hline
\end{tabular}

${ }^{*}$ Averages followed by the same letter in the column do not differ significantly by the Scott-Knott test at $5 \%$ probability of error. Values in parentheses: percentages about total produced relation.

Table 5. Pearson's correlation between litterfall and climate variables in the Semideciduous Seasonal Forest in Southern Brazil.

\begin{tabular}{lccc}
\multicolumn{1}{c}{ Fractions } & $\operatorname{Tmax}\left({ }^{\circ} \mathbf{C}\right)$ & $\mathrm{Tmin}\left({ }^{\circ} \mathbf{C}\right)$ & $\mathbf{P t}(\mathbf{m m})$ \\
\hline Leaves & -0.066 & $-0.307^{*}$ & -0.109 \\
Twigs & -0.248 & $-0.316^{*}$ & 0.075 \\
Miscellaneous & 0.049 & -0.124 & 0.062 \\
\hline${ }^{*}$ Significant correlation at 5\% probability of error. Tmin: average minimum air temperature; Tmax: average maximum air temperature; Pt: average pluviometric precipitation.
\end{tabular}




\section{CONCLUSIONS}

The litterfall amounts in the forest studied, which range from 7.09 to 8.57 $\mathrm{Mg} \mathrm{ha}^{-1}$ year $^{-1}$, correspond to values expected in the advanced successional stage. Leaves predominated in the litterfall composition (75\%), and thermal stress influences the litterfall amount, when minimum air temperature was negatively correlated with leaves and twigs production.

The litterfall is a relevant mean of forest nutrition in natural ecosystems; however, to better understand the nutrient cycling in Semideciduous Seasonal Forest, further studies are necessary to evaluate the nutritional and organic composition (cellulose, hemicellulose and lignin) of the litter and its decomposition dynamics (release of nutrients rate, decomposing fauna action, etc.).

\section{ACKNOWLEDGEMENTS}

We thank the company Araupel S.A. for providing the study area and for financial assistance. Thanks to Conselho Nacional de Desenvolvimento Científico e Tecnológico (CNPq) for granting scholarship to the first author of the study.

\section{SUBMISSION STATUS}

Received: 20 June 2018

Accepted: 13 Dec. 2018

Associate editor: Rodrigo Studart Corrêa

(1) 0000-0002-9422-2629

\section{CORRESPONDENCE TO}

\section{Grasiele Dick}

Universidade Federal de Santa Maria (UFSM), Av. Roraima, 1.000, CEP 97105-900, Santa Maria, RS, Brasil

e-mail: grasidick@hotmail.com

\section{REFERENCES}

Alonso JM, Leles PSS, Ferreira LN, Oliveira NSA. Aporte de serapilheira em plantio de recomposição florestal em diferentes espaçamentos. Ciência Florestal 2015; 25(1): 1-11. $10.5902 / 1980509817439$

Dias HCT, Figueira MD, Silveira V, Fontes MAL, Oliveira-Filho AT, Scolforo JRS. Variação temporal de nutrientes na serapilheira de um fragmento de floresta estacional semidecidual Montana em Lavras, MG. Cerne 2002; 8(2): 1-16.

Empresa Brasileira de Pesquisa Agropecuária - EMBRAPA. Sistema brasileiro de classificação de solos. 3rd ed. Brasília, DF: EMBRAPA; 2013.

Ferreira ML, Silva JL, Pereira EE, Lamano-Ferreira APN. Litter fall production and decomposition in a fragment of secondary Atlantic Forest of São Paulo, SP, southeastern Brazil. Revista Árvore 2014; 38(4): 591-600. 10.1590/S0100-67622014000400002
Fundação de Pesquisas Florestais do Paraná - FUPEF. Conservação do bioma floresta com araucária: relatório final: diagnóstico dos remanescentes florestais. Curitiba: FUPEF; 2001.

Ivanauskas NM, Assis MC. Formações florestais brasileiras. In: Martins SV, editor. Ecologia de florestas tropicais no Brasil. Viçosa: Editora UFV; 2012. p. 252-293.

Kimmins JP. Forest ecology. New York: Collier Macmillan Canada; 1987.

König FG, Schumacher MV, Brun EJ, Seling I. Avaliação da sazonalidade da produção de serapilheira numa floresta estacional decidual no município de Santa Maria-RS. Árvore 2002; 26(4): 429-435. 10.1590/S0100-67622002000400005

Lopes MIS, Domingos M, Struffaldide YV. Ciclagem de nutrientes minerais. In: Sylvestre LS, Rosa MMT. Manual metodológico para estudos botânicos na Mata Atlântica. Seropédica: EDUR; 2002. p. $72-102$.

Martins SV, Rodrigues RR. Produção de serapilheira em clareiras de uma floresta estacional semidecidual no município de Campinas, SP. Revista Brasileira de Botânica 1999; 22(3): 405-412. 10.1590/ S0100-84041999000300009

Matzenauer R, Radin B, Almeida IR, editors. Atlas climático do Rio Grande do Sul. Porto Alegre: FEPAGRO; 2011.

Menezes CEG, Pereira MG, Correia MEF, Anjos LHC, Paula RR, Souza ME. Aporte e decomposição da serapilheira e produção de biomassa radicular em florestas com diferentes estágios sucessionais em Pinheiral, RJ. Ciência Florestal 2015; 20(3): 439452. 10.5902/198050982059

Pereira MG, Menezes LFT, Schultz N. Aporte e decomposição da serapilheira na Floresta Atlântica, Ilha da Marambaia, Mangaratiba, RJ. Ciência Florestal 2008; 18(4): 443-454. 10.5902/19805098428

Pezzato AW, Wisniewski C. Produção de serapilheira em diferentes seres sucessionais da floresta estacional semidecidual no oeste do Paraná. Floresta 2006; 36(1): 111-120. 10.5380/rf.v36i1.5596

Pimenta JA, Rossi LB, Torezan JMD, Cavalheiro AL, Bianchini E. Produção de serapilheira e ciclagem de nutrientes de um reflorestamento e de uma floresta estacional semidecidual no sul do Brasil. Acta Botanica Brasilica 2011; 25(1): 53-57. 10.1590/S010233062011000100008

Pinto SIC, Martins SV, Barros NF, Dias HCT. Ciclagem de nutrientes em dois trechos de floresta estacional semidecidual na reserva florestal Mata do Paraíso em Viçosa, MG, Brasil. Árvore 2009; 33(4): 653-663. 10.1590/S0100-67622009000400008

Poggiani F. Ciclagem de nutrientes em florestas do Brasil. In: Martins SV, editor. Ecologia de florestas tropicais no Brasil. Viçosa: Editora UFV; 2012. p. 175-251.

Santos Neto AP, Barreto PAB, Gama-Rodrigues EF, Novaes AB, Paula A. Produção de serapilheira em floresta estacional semidecidual e em plantios de Pterogyne nitens Tul. e Eucalyptus urophylla S. T. Blake no sudoeste da Bahia. Ciência Florestal 2015; 25(3): 633-643. $10.5902 / 1980509819614$

Silva FAS, Azevedo CAV. Versão do programa computacional Assistat para o sistema operacional Windows. Revista Brasileira de Produção Agroindustrial 2002; 4(1): 71-78.

Taiz L, Zeiger E. Fisiologia vegetal. 5th ed. Porto Alegre: Artmed; 2013. 
Toledo LO, Pereira MG, Menezes CEG. Produção de serapilheira e transferência de nutrientes em florestas secundárias localizadas na região de Pinheiral, RJ. Ciência Florestal 2002; 12(2): 9-16. 10.5902/198050981676

Viani RAG, Costa JC, Rozza AF, Bufo LVB, Ferreira MAP, Oliveira ACP. Caracterização florística e estrutural de remanescentes florestais de Quedas do Iguaçu, sudoeste do Paraná. Biota Neotropica 2011; 11(1): 115-128. 10.1590/S167606032011000100011
Vital ART, Guerrini IA, Franken WK, Fonseca RCB. Produção de serapilheira e ciclagem de nutrientes de uma floresta estacional semidecidual em zona ripária. Árvore 2004; 28(6): 793-800. 10.1590/S0100-67622004000600004

Werneck MS, Pedralli G, Gieseke LF. Produção de serapilheira em três trechos de uma floresta semidecídua com diferentes graus de perturbação na Estação Ecológica do Tripuí, Ouro Preto, MG. Revista Brasileira de Botânica 2001; 24(2): 195-198. 10.1590/S0100-84042001000200009 